\title{
An Analysis on the Blended Teaching Reform on Project Implementation for English Majors in Dalian Neusoft University of Information
}

\author{
Qi Kang \\ Dalian Neusoft University of Information, No.8 Software Park Road, Dalian, Liaoning, China \\ kangqi@neusoft.edu.cn
}

Keywords: Blended Teaching Reform, Project Implementation, English Major.

\begin{abstract}
In the recent decades, as a member of the international organizations of engineering education, Dalian Neusoft University of Information has introduced the concept of project-based teaching into its curriculum construction. In DNUI, projects have been classified into five different levels in teaching and have been designed for the purpose of cultivating students' comprehensive qualities. The project of Next Stop the World, and the Workplace English Language Project I and II have been designed at the course level and are open to students in their first, second and third practice semesters respectively. With the development of information technology, blended teaching model has gained an increasing popularity among higher educational institutions. The project implementation in DNUI has also taken reforms accordingly. It now focuses on the construction of flexible teaching resources and the design of flipped classroom with pre-class, in-class and after-class activities. So far, the blended teaching model for project implementation has successfully motivated English major students to their full potentials and has made great contribution to the cultivation of professional talents in DNUI.
\end{abstract}

\section{Introduction to blended teaching model}

Blended teaching model is an approach to teaching that combines face-to-face and web-based online teaching experiences. It has been used to supplement, transform and even improve the learning process. Successful blended learning occurs when technology and teaching inform each other.[1] There are many benefits to the blended delivery of the course content. For universities, blended courses can be a strategy to compensate for the limited classroom space and the insufficient teaching resources. For teaching faculties, blended courses can be a method to infuse new engagement opportunities into the established courses. For students, blended courses offer the convenience of online learning together with the instructional interactions in the classroom.

To be more specific, in a traditional classroom, teachers usually use class time to give lectures. Students go over the knowledge after class and complete the assignments on their own. But in a blended teaching classroom, teachers use online media to deliver notes, lectures and other course-related teaching resources before class. During class time, as the facilitator, they engage discussions and offer other support for students' learning. Students can go over the knowledge at their own pace. It reinforces student-centered learning and succeeds in transforming passive learning into a truly interactive one.

\section{Introduction to project-based teaching}

\subsection{Definition of project-based teaching}

Project-based teaching is a student-centered pedagogy that involves a dynamic classroom approach in which students are believed to acquire a deeper understanding of knowledge through active exploration of the real world challenges and problems.[2] It is a style of active and inquiry-based learning and contrasts with teacher-led instructions that present established facts or portrays a smooth path to knowledge. So far, project-based teaching model has successfully created engaging learning experiences for students. 


\subsection{Project teaching for English majors in DNUI}

In DNUI, the project-based teaching model has been implemented at five different levels. During the three practice semesters, English major students participate in the project implementation at the course group level.[3] The project of Next Stop the World enables students to improve their language proficiency and acquire knowledge in the fields of humanities and social sciences. Through the research and the analysis of the subject development in the foreign universities, students show better performance in language acquisition and gain better understanding of the cultural differences, especially on campus. In the second practice semester, the Workplace English Language Project I is designed in accordance with the working process of foreign enterprises. Students participate in the team-building activities, new product launch, client entertaining activities, business report writing and venture capital conference. The project improves their abilities in language acquisition, commerce and cross-cultural communication and makes them qualified for free communication with foreigners in the working environment. For Workplace English Language Project II, students are required to make service selection according to the market research, analyze the micro and macro environmental factors and conduct data analysis. They are also instructed to do SWOT analysis and finally design the marketing plan. The project is quite beneficial to students who are going to enter the job market and are willing to explore business running models and conduct marketing researches.

\section{Blended teaching reform on project implementation}

\subsection{Construction of flexible teaching resources}

Blended teaching reform focuses on the integrated design of pre-class, in-class and after-class teaching activities. The purpose is to activate and motivate students for learning. Before-class tasks are designed for students to get well prepared for the in-depth learning activities and after-class assignments guide them to review and apply knowledge. The teaching resources are flexible in that they are designed with advanced technology and are accessible for online learning. Please refer to table 1 for more information about the construction of flexible teaching resources for English majors in DNUI:

Table 1: Construction of Flexible Teaching Resources

\begin{tabular}{|c|c|c|c|}
\hline \multirow{2}{*}{$\begin{array}{c}\text { Practice } \\
\text { Semester Projects }\end{array}$} & \multicolumn{2}{|l|}{ Resources } & \multirow{2}{*}{$\begin{array}{l}\text { Teaching } \\
\text { Objectives }\end{array}$} \\
\hline & Micro-course Resources & Other Resources & \\
\hline Next Stop the World & $\begin{array}{l}\square \text { introduction of cultural shock } \\
\square \text { how to compose a report } \\
\square \text { introduction of foreign universities } \\
\square \text { Information collection and analysis } \\
\square \text { how to design application documents }\end{array}$ & $\begin{array}{l}\square \text { self-study guide } \\
\square \text { cases for analysis } \\
\square \text { survey report template } \\
\square \text { resume template } \\
\square \text { extended learning } \\
\text { resources }\end{array}$ & $\begin{array}{l}\square \text { overseas study } \\
\text { preparation and } \\
\text { application }\end{array}$ \\
\hline $\begin{array}{l}\text { Workplace English } \\
\text { Language Project I }\end{array}$ & $\begin{array}{l}\square \text { how to make company introduction } \\
\square \text { how to design team-building activities } \\
\square \text { how to launch new products } \\
\square \text { how to entertain clients } \\
\square \text { how to write business report }\end{array}$ & $\begin{array}{l}\square \text { self-study guide } \\
\square \text { reading resources } \\
\square \text { cases for analysis } \\
\square \text { extended learning } \\
\text { resources }\end{array}$ & $\begin{array}{l}\square \text { venture capital } \\
\text { conference for } \\
\text { new products }\end{array}$ \\
\hline $\begin{array}{l}\text { Workplace English } \\
\text { Language Project II }\end{array}$ & $\begin{array}{l}\square \text { introduction of marketing } \\
\square \text { how to design a survey plan } \\
\square \text { how to design a questionnaire } \\
\square \text { how to do SWOT analysis } \\
\square \text { how to design a marketing plan } \\
\square \text { how to advertise }\end{array}$ & $\begin{array}{l}\square \text { self-study guide } \\
\square \text { cases for analysis } \\
\square \text { marketing plan } \\
\text { template } \\
\square \text { extended learning } \\
\text { resources }\end{array}$ & $\begin{array}{l}\square \text { marketing plan } \\
\text { for a service } \\
\text { project }\end{array}$ \\
\hline
\end{tabular}

For the project of Next Stop the World, students first explore the meaning of cultural shock, then they get to know how to compose a report. With online researches on foreign universities, they learn how to collect and analyze information. Finally, they design documents for overseas study 
preparation and application. For Workplace English Language project I, students are required to prepare the company introduction, design team-building activities, launch new products and entertain clients. Finally they plan their business report for the venture capital conference. For Workplace English Language project II, students learn to design a survey plan and do the SWOT analysis. Then they design a marketing plan for the service product.

The purpose for designing flexible teaching resources for the practice semester projects is to get students motivated for learning and improve their learning efficiency. The flexible resources function as an irreplaceable part of the integrated design of pre-class, in-class and after-class teaching. For the pre-class self study, resources are mainly in the form of online micro-course videos for reference. These resources are at different levels of complexity to guarantee students' effective learning experience. Through before-class self-study, students learn theoretical knowledge, find the confusing parts and do online researches to find the answer. For example, for the Workplace English Language Project II, students first figure out what SWOT analysis refers to and learn how to apply it in real working environment. After that, they analyze the four perspectives through case analysis. What they learn before class will guide them in the in-class discussion and the following project implementation section. For the project of Next Stop the World, students are required to preview the micro-course video on how to design application documents. Then they learn to apply the knowledge gained to make overseas study preparation and application. The project is implemented under the theoretical guidance and students are fully motivated throughout the whole process. Micro-course teaching videos maximize students' learning efficiency and fulfill the goal of enhancing their practical skills.

\subsection{Application of teaching platforms}

With the development of information technology, Foreign Language Institute in DNUI has been successful in designing the integrated project system. It gradually enhances students' abilities to solve problems in the real world and improves their comprehensive qualities as well. Meanwhile, the success in the implementation of course projects can not be achieved without the application of intelligent learning platforms. For example, Blue Mo Class platform, Class School platform and the Rain Class platform are quite popular among educational institutions. They are applicable to project implementation and result in better teaching effects. Please refer to Table 2 for more information about the application of intelligent teaching platforms:

Table 2: Intelligent Teaching Platforms

\begin{tabular}{|c|c|c|}
\hline Projects & Platform & Functions \\
\hline Next Stop the World & Rain Class & $\begin{array}{l}\text { online sharing of teaching resources } \\
\text { online testing } \\
\text { a teaching resources shared online with embedded video } \\
\text { instructions }\end{array}$ \\
\hline $\begin{array}{l}\text { Workplace English } \\
\text { Language Project I }\end{array}$ & Blue Mo Class & $\begin{array}{l}\text { - online sharing of teaching resources } \\
\text { - task allocation } \\
\text { questionnaire } \\
\text { Q\&A or discussion } \\
\text { online testing }\end{array}$ \\
\hline $\begin{array}{l}\text { Workplace English } \\
\text { Language Project II }\end{array}$ & Class School & $\begin{array}{l}\text { - pre-class assignment } \\
\text { - teaching resources shared online with embedded video } \\
\text { instructions } \\
\text { - sharing of teaching materials on Wechat platform } \\
\text { - instant reply from teacher/inquiry from the students }\end{array}$ \\
\hline
\end{tabular}

The intelligent platforms are multifunctional with obvious advantages. As for the Blue Mo Class platform, it is easy to sign up for the first time application. It is quite multifunctional because users can easily upload or download teaching resources. There are also opportunities for online discussion and for students to get instant reply from the teacher. It is quite convenient compared with traditional paper testing system. The instruction through the Rain Class platform can be reserved online for subsequent learning activities. It is quite suitable for individualized learning and 
break the barrier of traditional teaching methods. To sum up, the intelligent teaching platforms maximize students' passion for learning and integrate knowledge teaching with educational technologies.

\section{Conclusion}

The application of information technology in higher education is an irresistible development trend. The introduction of blended teaching model signifies a great step-forward for teaching. With a focus on the project-based teaching and the design of flipped classroom, universities provides a dynamic classroom which maximizes students' potential. Education no longer equals teacher-centered lectures or teacher-led instructions. Its functions have been greatly expanded. The blended teaching reform on project implementation for English majors in DNUI has set an example for others to follow and needs gradual improvement.

\section{References}

[1] The Definition of Blended Learning. https://www.teachthought.com/learning/the-definition-ofblended-learning/. Accessed July 6, 2019.

[2] Project-based Learning. https://en.wikipedia.org/wiki/Project-based_learning. Accessed July 18, 2019. [Wikipedia]

[3] Tao, Wen. Explore and build an integrated TOPCARES-CDIO talent training mode, China Higher Education, 2011. 